\title{
実地試験による室内空気中のホルムアルデヒドの測定における パッシブサンプラーとアクティブサンプラーとの比較
}

\author{
北見 秀明 ${ }^{\circledR 1}$, 渡辺 哲男 ${ }^{2}$, 北原 滝男 ${ }^{3}$, 石原 良美 ${ }^{3}$, 高野 二郎 ${ }^{3}$
}

Comparison between passive and active samplers for the determination of formaldehyde in indoor air by field test

\author{
Hideaki Kitami ${ }^{1}$, Tetsuo Watanabe ${ }^{2}$, Takio Kitahara ${ }^{3}$, \\ Yoshimi IshiHARA ${ }^{3}$ and Jiro TAKANO ${ }^{3}$
}

\footnotetext{
${ }^{1}$ Sougou Kankyou Bunseki Co., Ltd., 1 - 13 - 2, Kamoi, Midori-ku, Yokohama-shi, Kanagawa 226-0003

${ }^{2}$ Department of Resources and Environmental Science, School of Humanities and Culture, Tokai University, 1117, Kitamaname, Hiratsuka-shi, Kanagawa 259- 1292

${ }^{3}$ Derpartment of Chemistry, School of Science, Tokai University, 1117, Kitamaname, Hiratsuka-shi, Kanagawa $259-1292$
}

(Received 27 February 2003, Accepted 27 June 2003)

\begin{abstract}
我が国の公定法では，室内空気中のホルムアルデヒド（HCHO）の測定においてアクティブサンプラ ーとパッシブサンプラーが認められている。 また両法どちらのサンプリング方法を用いても HCHO の判 定基準は $100 \mu \mathrm{g} \mathrm{m}{ }^{-3}$ となっている。 そこで水質検査室内における実地試験により，両法の比較を行った. その結果，まず 2,4-ジニトロフェニルヒドラジン（DNPH）誘導体化法を用いた高速液体クロマトグラフ イー/紫外分光光度法による HCHO-DNPH の測定において，本測定条件下ではその検出限界は $S / N=3$ で $0.0025 \mathrm{mg} \mathrm{l}^{-1}$ であった. また検量線の直線性は $0.005 \sim 0.5 \mathrm{mg} \mathrm{l}^{-1}$ で相関係数 $0.999 \sim 1$ が得られ，良 好であった．次にサンプリング方法の検討では，両法で測定值に差が生じることが確認できた.
\end{abstract}

Keywords : formaldehyde (HCHO); sampler; HPLC-UV; 2,4-dinitorophenylhydrazine (DNPH); indoor air; field test.

\section{1 はじめに}

近年，電力等に対する省エネルギーの意識から，気密性 の高い建築物が増加し，技術の進歩により住宅やビルの建 材・内装材として多くの新素材が開発され使用されるよう になってきた。その影響で，住宅やビルの建材からホルム アルデヒド（formaldehyde, HCHO）や揮発性有機化合 物（volatile organic compounds, VOCs）などの化学物質 が放散されるようになり, 屋外よりも室内のほうがこれら

\footnotetext{
${ }^{1}$ 株式会社総合環境分析技術部：226-0003 神奈川県横浜市緑区 鴨居 1-13-2

2 東海大学教養学部人間環境学科 : 259-1207 神奈川県平塚市北 金目 1117

3 東海大学理学部化学科：259-1207 神奈川県平塚市北金目 1117
}

物質の濃度が高くなってきている．特にこれら化学物質に よる人体への影響が問題となっており，シックハウス症候 群と呼ばれる現象が顕在化してきたことにより, 室内濃度 のモニタリングが重要視されてきた ${ }^{1) \sim 3)}$.

このシックハウス症候群において，我が国で最初に問題 となった化学物質に HCHO がある。この HCHO の測定 には, 公定法 ${ }^{4) \sim 6)}$ で規定されている黄色の 2,4-ジニトロフ エニルヒドラジン (2,4-dinitrophenylhydrazine, DNPH) で誘導体化（2,4-dinitorophenylhydrazone，ヒドラジン誘 導体）して高速液体クロマトグラフィー/紫外分光光度法 （HPLC-UV）で行うことが多い.また，これらの測定にお ける検討は各種測定機関で行われている77.

室内の HCHO の捕集には，公定法 ${ }^{4)}$ (6) で規定されてい る，アクティブサンプラーによる DNPH 含浸カートリッ 
ジを用いた方法が主に用いられている。また最近では，ポ ンプやガスメーターを必要としない簡易測定法として, DNPH 含浸パッシブサンプラーを用いるようになってき $た^{8) 9}$. これら捕集方法についての検討は, 公定法 ${ }^{10)}$ とし て採用されたチャンバー試験で行った結果が多い ${ }^{11) \sim 13)}$. しかし小型や大型のチャンバー試験の結果は, 污染物質の 発生源からの拡散が起こりやすく, 定常状態での検討であ り，更に捕集時間を合わせた上で測定を行っているため， パッシブサンプラーとアクティブサンプラーとの関係にお いて良い HCHO 濃度の一致や濃度の相関関係が得られる が，通常の室内においては温度や湿度等を保持したとして も，污染物質が非定常状態で存在している可能性もあるた め, 必ずしもそれぞれの濃度の一致が得られるとは限らな い. しかも個人暴露による人体への影響は，通常の生活環 境で起こるため, 強制的に密閉状態にして污染物質を拡散 させて濃度を測定したとしても，発生源の特定等を含め人 体への影響の解明にはつながりにくい。また，DNPH は HCHO 以外にもカルボニル基（-CHO）を有する物質には すべて反応してしまう上に，室内環境によってはその他の 共存物質が存在するため, 測定において妨害を起こす可能 性もある。

最近, 新たに我が国の厚生労働省 ${ }^{14)}$ 及び文部科学省 ${ }^{15)} に$ おいて，シックハウス関連の検査方法が告示された。それ らによると, 採取時間は吸引方式 (アクティブサンプラー) では 30 分間で 2 回以上, 拡散方式 (パッシブサンプラー) では 8 時間以上とするとなっている.また判定基準（規 制值）はどちらの方法でも HCHO は $100 \mu \mathrm{g} \mathrm{m}^{-3}(0.08$ $\mathrm{ppm}$ ）以下であることとしている。これらによると，採 取方法に差がないことから，規制值が同じであることが前 提条件と判断できる。もしもこれらの公定法 ${ }^{14) 15)}$ で測定を 行って，採取方法によって測定值に差が生じるとしたら， 各検査機関において実務上, 測定方法の判断にたいへん苦 慮することになる。

そこで本研究では，HCHO の捕集及び測定妨害物質で あるカルボニル基を有するアセトン等の有機溶剤が微量に 存在すると思われる水質検査室内において, 実務中の場合 と同様に適宜に換気を行いながら HCHO の人為発生源を 設置した実地試験を行い, HPLC-UV 測定によるパッシブ サンプラーとアクティブサンプラーとの比較を行ったの で，その結果について報告する.

\section{2 実 験方法}

\section{$\mathbf{2} \cdot \mathbf{1}$ 試 薬}

HCHO-DNPH 標準品はアセトニトリルに溶かして 100 $\mu \mathrm{g} \mathrm{ml}^{-1}$ に調製してある関東化学製の環境分析用を使用し た。またアセトニトリルは関東化学製の HPLC 用を使用 し, 人為発生源として使用したホルムアルデヒド溶液（ホ
ルマリン）は国産化学製の試薬特級（含量 $35 \%$ ）を使用 した。その他の試薬に関しては，和光純薬製の試薬特級を 使用した。また分析に用いた水は，オートスチール（ヤマ 卜科学製 YG221）により精製した蒸留水 $(0.2 \mu \mathrm{S} / \mathrm{cm}$ 以下 $)$ を使用した。

$10 \mu \mathrm{g} \mathrm{ml}^{-1}$ の標準原液は, $100 \mu \mathrm{g} \mathrm{ml}^{-1}$ の HCHO-DNPH 標準品からアセトニトリルを溶媒として用時調製した。こ の標準原液を適宜アセトニトリルで希釈し, 各濃度段階の 標準液を用時調製し使用した。

\section{$2 \cdot 2$ 測定装置及び条件}

HPLC システムは，ポンプ（655A-11），紫外分光光度検 出器 (655A-21), カラムオーブン (L-7300, 以上, 日立製), 記録計（C-R6A，島津製）を使用した。測定条件は以下の とおりである。カラム, 関東化学製（Mightysil RP-18 GP, $150 \mathrm{~mm} \times 4.6 \mathrm{~mm}$ i.d., 粒径 $5 \mu \mathrm{m})$; カラムオーブン温度, $40{ }^{\circ} \mathrm{C}$; 溶離条件, アセトニトリル - 水 $=70: 30 \%$; 溶離液 流量, $0.5 \mathrm{ml} \mathrm{min}{ }^{-1}$; 测定波長, $360 \mathrm{~nm}$; 注入量, $20 \mu \mathrm{l}$.

また, HCHO-DNPH の定量には, 絶対検量線法により 検量線を作成し, 定量した。

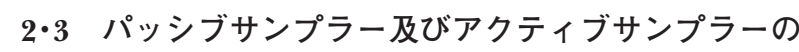

\section{捕集装置及び条件}

パッシブサンプラーは市販の DSD-DNPH（SUPELCO 製）を使用し，アクティブサンプラーは市販の Sep-Pak DNPH-Silica（long body，Waters 製）を使用した。またオ ゾンは，空気中のアルデヒドの測定の際に，DNPH 誘導 体化を妨害することが知られている( ${ }^{9) 12)}$. そのオゾンをヨ ウ化カリウムで除去するためによく使用されるオゾンスク ラバーは，パッシブサンプラーとの測定条件を等しくする ために使用しなかった。アアクティブサンプラー捕集時のガ スメーターは DRY TEST GAS METER DC-1（SHINAGAWA 製）を使用し，吸引ポンプは G-5DA（SINKU KIKO 製) を使用した.

パッシブサンプラーで捕集した HCHO の検液の作製手 順を以下に示した。まず，24 時間静置したパッシブサン プラーに捕集された HCHOは，DNPH と反応し DNPH 誘導体（HCHO-DNPH）になる。これをアセトニトリル で溶出し，アセトニトリルで $5 \mathrm{ml}$ に定容した後，HPLCUVにより測定した。

アクティブサンプラーでの捕集は公定法 ${ }^{4)}$ (6) に従って行 った. HCHO の検液の作製手順はパッシブサンプラーと 同様に行った。ガス吸引量は 301 とした。また，室内空 気の濃度計算方法は既報 ${ }^{4) ~ 6) 889) ~}$ と同様に行った.

$2 \cdot 4$ サンプリング

2003 年 2 月 $12 \cdot 13$ 日及び同年同月 $15 \cdot 16$ 日に (株) 総 


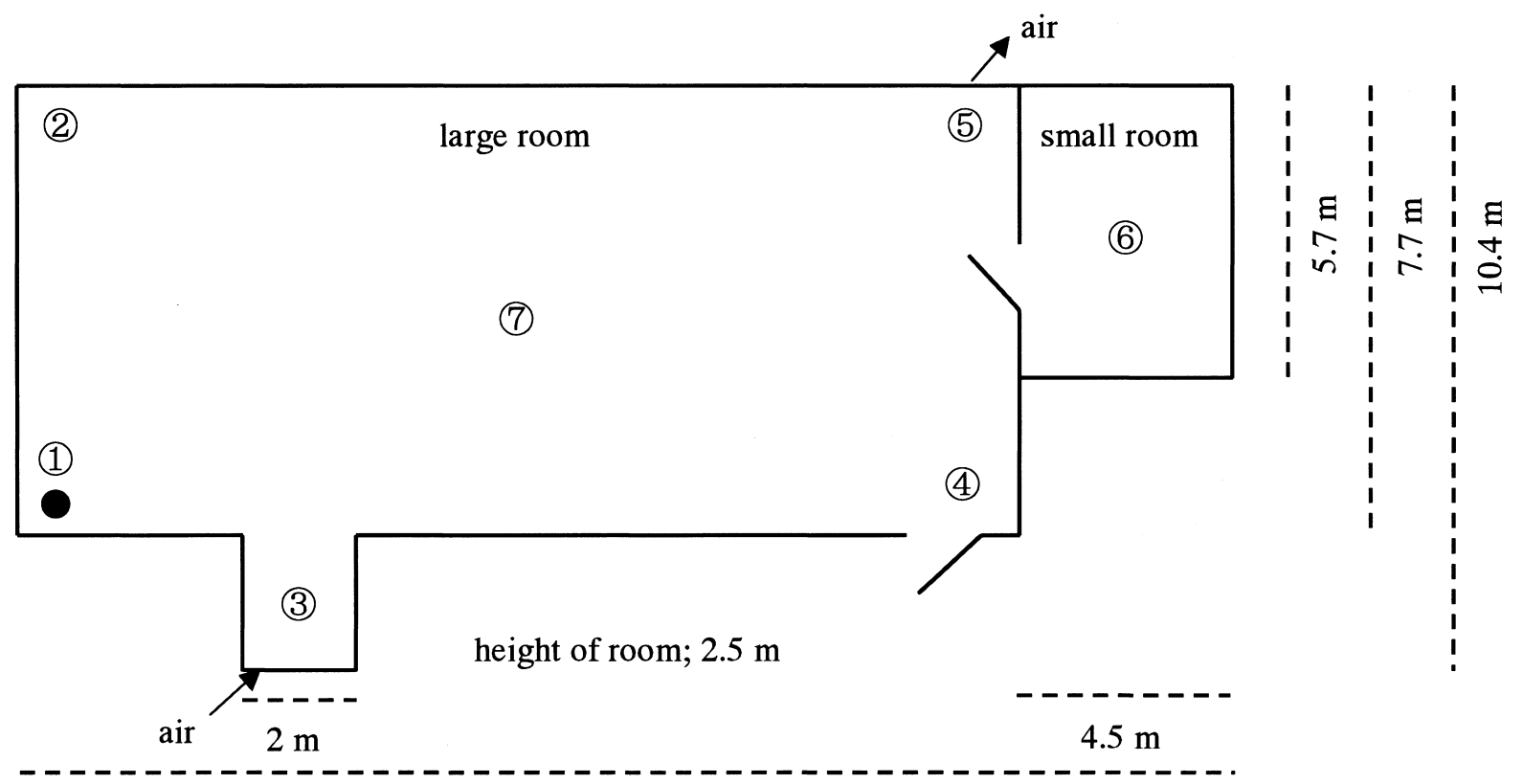

$19 \mathrm{~m}$

Fig. 1 Schematic view of the experimental small and large rooms

(1) (7): sampling point; : HCHO emission point

合環境分析内の大小 2 つの水質分析検査室（以下，検査 室）でサンプリングを行った。検査室の平面見取り図を Fig. 1 に示した. また，この検査室の空については Fig. 1 に示していないが，気密性は高く，サンプリング中は空の 開閉は行わなかった。

捕集地点の (1)〜 (5) は側面の壁から約 $50 \mathrm{~cm}$ 離れた地点 であり，(6)，(7) は各部屋の中心とした。大きい検査室は 出入り口, 換気口, 空調があり, 小さい検查室は出入り口, 空調がある．空調は四方に風が放出されるようになってお り, 各部屋の中央の天井にある. 出入り口の人の出入りは, 昼間（約 8 時 30 分〜 17 時）は 1 時間に 1 回程度あり, 夜 間（約 17 時〜 8 時）は人の出入りがない状態とした。ま た $\mathrm{HCHO}$ 発生源として, $100 \mathrm{ml}$ のビーカーに含量 $35 \%$ のホルマリンを $50 \mathrm{ml}$ 入れ, 地点 (1)に 24 時間放置した.

パッシブサンプラーの場合は，実験を始めてから 24 時 間後に回収して，その直後にHPLC-UVにより測定した。 アクティブサンプラーの場合は実験を始めてから 1 時間 後に 7 地点同時に公定法 ${ }^{4) \sim 6)}$ ど抒り一定流量で 301 捕集 し，その直後にHPLC-UVにより測定した．更に，アクテ イブサンプラーの場合は 24 時間後にも同様に捕集・測定 を行った。また両検査室でのサンプリング及び HPLC-UV 測定時の温度は, 約 $17^{\circ} \mathrm{C}$, 湿度約 $40 \%$, 大気圧 $101.5 \mathrm{kPa}$ でほぼ一定であった。

\section{3 結果と考察}

\section{$3 \cdot 1$ HPLC-UV 測定}

アセトニトリルを溶媒とした HCHO-DNPH 標準液及び アクティブサンプラーカートリッジとパッシブサンプラー カートリッジの空試験のクロマトグラムを Fig. 2 に示し た.

まず（a），(b) の結果から分かるように，標準液では HCHO-DNPH の保持時間は約 6.4 分であり, 約 $7 \sim 8$ 分 でベースラインが安定した。しかし（c)，（d）の結果か らも分かるように, DNPH 含浸のカートリッジの空試験 に拉いては 15 分ではベースラインが安定しなかった。ま た空試験で HCHO-DNPH が検出され，アクティブサンプ ラーではアセトニトリルで $5 \mathrm{ml}$ に定容した検液中の濃度 で平均 $0.010 \mathrm{mg} \mathrm{l}^{-1} \quad(n=5)$, パッシブサンプラーでは平 均 $0.005 \mathrm{mg} \mathrm{l}^{-1} \quad(n=5)$ であった.

次に, HCHO-DNPH 標準液を $0.005,0.01,0.05,0.1$, $0.5 \mathrm{mg} \mathrm{l} \mathrm{l}^{-1}$ に調製したもの 5 点から絶対検量線法により検 量線を作成した。本測定条件下では HCHO-DNPH におい て検量線の良好な直線性（相関係数 $r=0.999 \sim 1$ ）が得ら れた。このときの HCHO-DNPH の検出限界は $S / N=3$ で $0.0025 \mathrm{mg} \mathrm{l}^{-1}$ であった。また $0.01 \mathrm{mg} \mathrm{l^{-1 }}$ の標準液を繰り 返し測定 $(n=10)$ した結果，相対標準偏差が 0.93 1.10\%であった. 


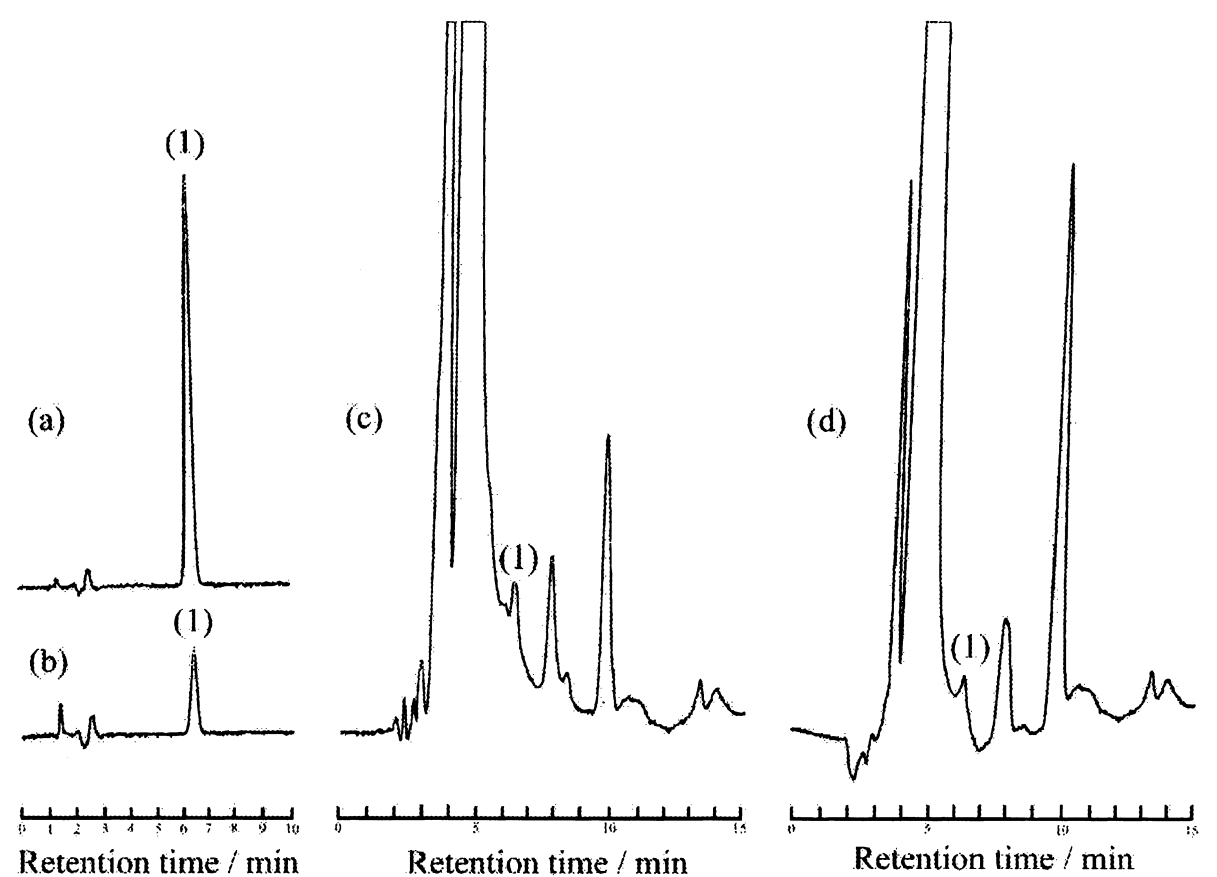

Fig. 2 HPLC-UV Chromatogram of HCHO-DNPH (20 $\mu$ l injection)

(1): HCHO-DNPH; (a): standard $\left(0.05 \mathrm{mg} \mathrm{l}^{-1}\right)$; (b): standard $\left(0.01 \mathrm{mg} \mathrm{l}^{-1}\right)$; (c): blank test of an active sampler; (d): blank test of a passive sampler

\section{$3 \cdot 2$ 実地試験}

Fig. 1 に示したそれぞれの検査室において，HCHOの 人為発生源を設置した室内空気中の HCHO 濃度の実測を 行った。

まず，測定点 (7)の HCHO を測定したときのクロマト グラムを Fig. 3 に示した. Fig. 3 は, Fig. 2 の (c), (d) と同様にアセトニトリルで $5 \mathrm{ml}$ に定容したときの検液を 無希釈で測定し，インテグレーターの拡大レベルも同じに したときの図である，定量の際には，この検液を検量線の 範囲内にまで希釈を行った後に測定した。

この結果から分かるように, HCHO 以外のカルボニル 基を有する化合物, DNPH の残存物質及びその他の共存 物質が存在していると思われるピークが数多く検出され た.また，このときの大小 2 つの検査室のアセトンの濃 度は $1 \mu \mathrm{g} \mathrm{m}^{-3}$ 以下であったが, Fig. 3 から明らかなよう に，その影響は現れた。

次に, Fig. 1 に示した各捕集地点（1)〜 (7)）における各 捕集法による測定值を Table 1 に示した.この結果から明 らかなように, パッシブサンプラーによる測定結果は, 発 生源の近くの (1) と大きな検査室の中心地点の (7) で他の 測定点より若干濃度が高くなってはいるものの, その他の 各地点においてはほぼ同じ濃度を示した。 それに対してア クティブサンプラーによる測定結果は, 各地点によって大 きな濃度の偏りが見られた. 特に当然の現象として発生源 において規制值の $100 \mu \mathrm{g} \mathrm{m}^{-3}$ 近くの $56.8 \sim 97.7 \mu \mathrm{g} \mathrm{m}^{-3}$
(1)
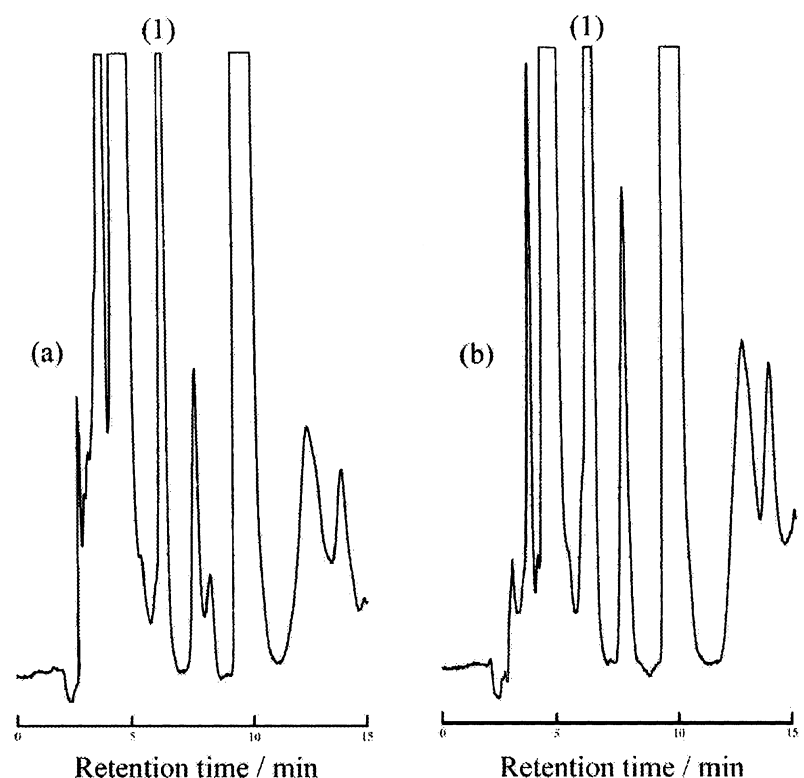

Fig. 3 HPLC-UV Chromatogram of indoor air at sampling point 7 (20 $\mu$ l injection)

(1): HCHO-DNPH; (a): active sampler; (b): passive sampler

を示したまた濃度の偏りの結果を見ると，(2)，(4)にお いて濃度が低くなり, 通気口からの外気の流れに沿って発 生源からの濃度の変動が見られ, 室内において HCHO が 複雑に対流していると思われる結果が得られた。よって室 
Table 1 Results of field-measurement of HCHO in the small and large rooms by passive and active samplers

\begin{tabular}{|c|c|c|c|}
\hline \multirow{2}{*}{ Sampling point } & \multicolumn{3}{|c|}{ Concentration of $\mathrm{HCHO} / \mu^{-3} \mathrm{~g} \mathrm{~m}^{-3}$ (Feb. 12-13, 2003/Feb. 15-16, 2003) } \\
\hline & $\begin{array}{l}\text { Active sampling } \\
\text { (after } 1 \text { hour) }\end{array}$ & $\begin{array}{l}\text { Active sampling } \\
\text { (after } 24 \text { hour) }\end{array}$ & $\begin{array}{l}\text { Passive sampling } \\
\text { (after } 24 \text { hour) }\end{array}$ \\
\hline (1) & $97.7 / 96.9$ & $56.8 / 69.1$ & $18.6 / 20.8$ \\
\hline (2) & $0.3 / 1.6$ & $0.4 / 2.3$ & $14.5 / 18.5$ \\
\hline (3) & $1.5 / 2.4$ & $2.2 / 3.5$ & $14.9 / 19.1$ \\
\hline (4) & $0.1 / 1.1$ & $0.3 / 1.9$ & $14.5 / 18.3$ \\
\hline (5) & $1.8 / 2.7$ & $2.4 / 3.1$ & $15.2 / 18.9$ \\
\hline (6) & $1.2 / 2.1$ & $2.3 / 2.4$ & $5.9 / 7.8$ \\
\hline (7) & $6.3 / 8.6$ & $11.4 / 10.6$ & $17.6 / 19.2$ \\
\hline
\end{tabular}

内に発生源があった場合, 大きい検査室においてはパッシ ブサンプラーとアクティブサンプラーとの測定值の一致は 得られなかった。 また小さい検査室では HCHO の発生源 がないために，両サンプリング方法で低い值となり，パッ シブサンプラーとアクティブサンプラーとの測定值の差は 大きい検査室ほど見られなかった。 しかし，常にアクティ ブサンプラーのほうが低い測定值を示した。 これらの結果 は，他の日に数回同様の調査を行った場合においても同様 であった。

これらの結果から, 実地試験において, JIS 等の公定法 によるアクティブサンプラーによる捕集と簡易測定法であ るパッシブサンプラーによる捕集とでは測定值に差が生じ ることが確認できた。 またアクティブサンプラーによる測 定の結果，室内における発生源からの拡散は，実験開始後 1 時間程度では発生源近傍（測定点 (1)）が高く，他の室 内各測定点（測定点 (2), (3), (4), 5), 7) では発生源近 傍の $1 \sim 3 \%$ 程度と低かった。この状況は 24 時間後に再 測定した場合もその傾向に変化はなかった。 パッシブサン プラーでは，この傾向は見られず，一部の隔離された小部 屋（測定点 (6)）以外では比較的濃度変動は小さかった.

\section{文献}

1) 松村年男，安藤正典：資源環境対策, 31, 15 (1995).

2) 花井義道, 陳 永紅, 中西順子: 横浜国大環境研紀 要, 22, 1 (1996).

3) 松木秀明: 大気環境学会誌, 33, A19 (1998).

4) US Environmental Protection Agency: EPA method TO-11 (1988).

5) JIS K 0303, 排ガス中のホルムアルデヒド分析方法 (1993).

6) 環境庁大気保全局大気規制課: “有害大気污染物質 測定法マニュアル”, (1997).

7) 今村 清, 江口正治，大平修平，白國忠志，竹中 規訓，田代恭久，立花茂雄，平井恭三，藤方 豊， 矢坂裕太: 分析化学 (Bunseki Kagaku), 52, 73 (2003).

8) US Environmental Protection Agency: EPA method IP-6C (1990).

9) S. Uchiyama, S. Hasegawa: Atmos. Environ., 33, 1999 (1999).

10) JIS A 1901, 小型チャンバー法による測定方法 (2003).

11) G. E. Myers, M. Nagaoka: Forest Prod. J., 31, 39 (1981).

12）関根嘉香, 佛願道男，臼杵英俊，北原滝男：環境化 学, 11, 511 (2001).

13) 石丸 章: 神奈川県産業技術総合研究所報告, 8, 56 (2002).

14) 厚生労働省：第 9 回シックハウス問題に関する検討 会中間報告 (2002).

15) 文部科学省: 文部科学省スポーツ・青少年局長「学 校環境衛生の基準」裁定一部改訂 (2002). 